\title{
Hygienic Quality of Minced Meat Retailed in Western Algeria
}

\author{
Bouzid $^{1}$ R., Guemour ${ }^{2}$ D., Zidane ${ }^{3}$ K.,Aggad* ${ }^{4}$ H., Bendella ${ }^{4}$ A., Saegerman ${ }^{5}$ C. \\ ${ }^{1}$ Higher School of veterinary science, Algiers, Algeria \\ ${ }^{2}$ Faculty of nature and life science, University Ibn khaldoun of Tiaret, 14000 Algeria* \\ ${ }^{3}$ Institute of Veterinary Science, University Ibn Khaldoun of Tiaret, 14000 Algeria \\ ${ }^{4}$ Laboratory of Hygiene and Animal Pathology, Institute of Veterinary Science, University Ibn \\ Khaldoun of Tiaret, 14000 Algeria
}

\footnotetext{
${ }^{5}$ Research Unit of Epidemiology and Risk Analysis applied to Veterinary Science, Department of Infectious and Parasitic Diseases, Faculty of Veterinary Medicine, University of Liege, B42, Boulevard de Colonster, 20, B-4000 Liege, Belgium
}

Correspondence should be addressed to: H. Aggad; h_aggad@yahoo.com

Received date: 23 January 2014; Accepted date: 30 August 2014; Published date: 08 May 2015

Academic Editor: Nalan Gökoğlu

\begin{abstract}
The meat is regarded as one of the main sources of food-borne diseases; its evaluation can constitute a valuable source of information that can be used in the design of the collective prophylaxis programs in public health. The purpose of this study consisted in evaluating the quality of two types of minced meat (frozen and fresh), 30 samples from each type were collected from butchers in warm season (May-June) in the region of western Algeria. The analyses of laboratories have focused on the total aerobic mesophilic flora (TAMF), total coliforms (TC), fecal (FC), spores of sulfite-reducing clostridia (SRC), Staphylococci (Stap) and salmonella. Psychrophilic bacteria were investigated at the frozen meat and yeast at the fresh meat. Expressed as log cfu/g of meat; the overall results were 4.88, 3.89, 3.08, 2.09 and 4.45 respectively for TAMF, TC, FC, SRC and Stap. The fresh minced meat appeared more contaminated than the frozen one but the difference is significant only for total mesophilic flora and total coliforms. Salmonella was isolated only in frozen minced beef.
\end{abstract}

Keywords: Minced meat, hygiene, bacteriology, assessment.

\section{Introduction}

The consumption of meat, all species and offal would reach in Algeria in 2006 about $28.214 \mathrm{~kg} /$ inhabitant / year according to FAO (1).
Strict monitoring of the hygienic slaughter practices is essential in preventing microbial contamination of carcasses, as a corollary the protection of consumer health and meat quality. In fact, it was estimated 
that $80-90 \%$ of the meat microflora reaching consumers result from contamination occurring at the slaughterhouse (2).

The preparation of the minced meat begins with the boning of the meat during which it is difficult to avoid the contact between the meat-based surfaces freshly put in the air and those who are previously soiled.

This operation requires rigorous manipulator hygiene to minimize the contaminations, furthermore, the mincing operation accentuate the contamination of the meat by the passage in the chopper which is generally washed only at the end of the day.

The preparation in advance of a great quantity of minced meat and the break in the cold chain are so many elements which favor and accentuate the contamination.

If the organoleptic quality of meats can be appreciated by routine inspection, the fact remains that germ contaminations will be detectable only by laboratory analysis.

The objective of this study is to assess the hygienic quality of two types of minced beef (frozen and fresh) usually used in the region of Tiaret and Mostaganem (western Algeria). The hygienic quality is appreciated using a standardized sampling method, research and enumeration of hygienic interest but also with research of some pathogens as staphylococcus and salmonella.

\section{Materials and Methods}

\subsection{Sampling Procedure:}

The study was realized on 60 samples of minced beef; 30 samples of frozen beef (frozen MB) and 30 samples of fresh beef (fresh MB) randomly collected from butcher's shops of the city of Tiaret and of Mostaganem (Algeria). Frozen meats were imported from the Argentina, Brazil and India. The mincing is applied just before purchase.

By respecting the cold chain $\left(4{ }^{\circ} \mathrm{C}\right)$, collected samples (100 g) have been dispatched to the laboratory to be analyzed in the next two hours, aseptic samples are taken.

\subsection{Bacteriological Analyses}

Total Aerobic mesophilic flora (TAMF) (3): after 72 hours of incubation in PCA agar (Pasteur institute, Algiers), colonies between 15 and 300 are counted and the results expressed in colony forming units per gram of meat (cfu/g).

Total Aerobic psychrophilic flora (4): studied only for the samples of frozen meat (Frozen MB). The Incubation was done at 7 ${ }^{\circ} \mathrm{C}$ for 7 to 10 days; psychrophilic analysis is made in the same way as for the TAMF (in-depth culture on PCA). Only Petri dishes with a number of colonies between 15 and 300 are used for counting.

Yeasts and molds (5): studied only for the fresh meat (Fresh MB). The method consists in sowing the oxytetracycline glucose agar (OGA medium). The counting is realized after 3 to 5 days of incubation at $25^{\circ} \mathrm{C}$.

Total and fecal Coliforms (6): after an incubation of $24-48$ hours at $37^{\circ} \mathrm{C}$ for the total coliforms (TC) and at $44^{\circ} \mathrm{C}$ for the fecal (FC), Petri dishes which have 15 to 150 red colonies at least $0,5 \mathrm{~mm}$ in diameter are counted.

Staphylococcus aureus (stap) (7): counting and research have been carried out on Baird Parker agar by sowing on the surface with $0.1 \mathrm{ml}$ of the stock solution and its various dilutions and incubation of Petri dishes at $37^{\circ} \mathrm{C}$ for 48 hours. Highlighting thermonuclease and coagulase on black colonies surrounded by clear counted aureole allows concluding that they are the ones of Staphylococcus aureus. An enumeration is then realized.

Sulphite-reducing anaerobes spores (SRC): The incubation was performed at $37^{\circ} \mathrm{C}$ for 24 to 48 hours on Meat Liver agar. The big black colonies, producing sulphides from sulphites which precipitated with the iron ions, are considered as clostridia sulphitoreducers (8) 
Salmonella (9): Isolation is made on Hektoen agar (Pasteur Institute, Algiers) incubated at $37 \mathrm{C}^{\circ}$ for 24 hours. The characteristic colonies underwent morphological and biochemical identification.

All microbial counts were expressed as base-10 logarithms of colony forming units per gram $(\log \mathrm{cfu} / \mathrm{g})$.

\subsection{Statistical Analysis}

The confidence interval 95\% of prevalence rates of bacteria in the minced meat was estimated using an exact binomial distribution. The average logarithms of germs content in the minced beef (frozen and fresh) was compared by means of unequal variance Welch test (10).

\section{Results}

Global minced beef hygienic quality in western Algeria, according to the meat (frozen or fresh), is summarized in table 1. The global averages are expressed in arithmetic mean.

Table 1: Global Microbiological quality of minced meat $(\log \mathrm{cfu} / \mathrm{g})$

\begin{tabular}{|c|c|c|c|c|c|c|}
\hline MB & Germs & $\begin{array}{l}\text { Global } \\
\text { average }\end{array}$ & standard $^{\#}$ & Average & S-deviation & $\begin{array}{l}\text { P value (unequal } \\
\text { variance Welch test) }\end{array}$ \\
\hline Frozen & \multirow[t]{2}{*}{ TAMF } & \multirow[t]{2}{*}{4.88} & \multirow[t]{2}{*}{5.69} & 4.63 & 0.82 & \multirow[t]{2}{*}{$0.004^{*}$} \\
\hline Fresh & & & & 5.14 & 0.59 & \\
\hline Frozen & \multirow[t]{2}{*}{$\mathrm{TC}$} & \multirow[t]{2}{*}{3.89} & \multirow[t]{2}{*}{ n.d. } & 3.46 & 1.41 & \multirow[t]{2}{*}{$0.007^{*}$} \\
\hline Fresh & & & & 4.32 & 1.19 & \\
\hline Frozen & \multirow[t]{2}{*}{$\mathrm{FC}$} & \multirow[t]{2}{*}{3.08} & \multirow[t]{2}{*}{2} & 2.76 & 1.64 & \multirow[t]{2}{*}{0.06} \\
\hline Fresh & & & & 3.41 & 1.51 & \\
\hline Frozen & \multirow{2}{*}{ CSR } & \multirow[t]{2}{*}{2.09} & \multirow[t]{2}{*}{1.47} & 1.90 & 1.64 & \multirow[t]{2}{*}{0.33} \\
\hline Fresh & & & & 2.29 & 1.46 & \\
\hline Frozen & \multirow{2}{*}{ Stap } & \multirow{2}{*}{4.45} & \multirow{2}{*}{2} & 4.28 & 1.93 & \multirow{2}{*}{0.45} \\
\hline Fresh & & & & 4.61 & 1.41 & \\
\hline Frozen & Psyc & - & n.d. & 4.88 & 0.68 & - \\
\hline Fresh & $\mathrm{Ye}$ & - & n.d. & 4.51 & 0.69 & - \\
\hline
\end{tabular}

TAMF: total aerobic mesophilic flora, TC: total coliforms, FC: fecal coliform, SRC: sulfite-reducing clostridia, Stap: Staphyloccus aureus, Psyc: Psychrophilic flora, Ye: Yeast and molds; n.d.: not determined; * below $5 \%$ significance level;

\#Arrêté Interministériel du 24 janvier relatif aux spécifications microbiologiques de certaines denrées alimentaires, 1998, Journal officiel de la république algérienne, Nㅜ5, 11.

It appeared total aerobic mesophilic flora, and total coliforms were significantly higher in fresh meat. However, differences are not significant for the rest of germs.
Salmonella were only recovered in frozen MB (6.67) (Table 2). 
Table 2: Occurrence of Salmonella.

\begin{tabular}{|l|c|l|}
\hline Meat & Samples nb & $\begin{array}{l}\text { Presence in percent } \\
\text { (confidence interval 95 \%*) }\end{array}$ \\
\hline Frozen MB & 30 & $6.67(0.82-22.07)$ \\
\hline Fresh MB & 30 & $0(0-9.50)$ \\
\hline Frozen MB + Fresh MB & 60 & $3.33(0.41-11.53)$ \\
\hline
\end{tabular}

\section{Discussion}

Like any other raw food, minced beef may be contaminated during production, processing, storage and marketing with biological agents that may be harmful to human health (11).The global results showed that $96.66 \%(58 / 60)$ of the studied samples did not correspond to the statutory microbiological standards, widely exceeding those $(80 \%)$ reported in Morocco (12).

\section{Total aerobic mesophilic-Flora (TAMF)} and psychrophilic bacteria: It provides information on the overall degree of meat contamination and constitutes a criterion to classify slaughter-houses according to their hygienic quality (13).

The results (4.88 log $\mathrm{cfu} / \mathrm{g})$ are below to those obtained in Morocco in 80s, with 5.15 to $6 \log \mathrm{cfu} / \mathrm{g}(14 ; 15)$ or more recently, between 7,6 to $8,6 \log \mathrm{cfu} / \mathrm{g}(16 ; 17)$.

Other investigators could recover the organisms from minced meat samples in variable percentages such as in Nigeria (9.65 log cfu/g: 18), in the United Kingdom (6.11 log cfu/; 19), in U.S.A. (4.6 log cfu/g; 20 ) and in Turkey where $79 \%$ of the samples had high rates exceeding $5 \mathrm{log}$ $\mathrm{cfu} / \mathrm{g}(11)$.

The differences can be explained by the degree of hygiene monitoring at different stages of the meat production and preparation. In addition, in our study, most butchers have neither running water nor chilled choppers while wearing gloves remains a practice that is not yet installed. Similar causes would also explain the level of charges recorded for other studied germs.

The average of psychrophilic bacteria reaches $4.88 \mathrm{log} \mathrm{cfu} / \mathrm{g}$ joins that (3.7- 6.61 $\log \mathrm{cfu} / \mathrm{g}$ ) reported by Karaboz and Dincer (21). These germs and indicators of meat spoilage are used by some authors to classify slaughter- houses according to their hygienic quality (13).

Coliforms: Determination of Enterobacteriaceae is an essential element in quality assessment of slaughter hygiene, slaughter-houses and consumption meats (22).

The average charge in TC is of $3.89 \mathrm{log}$ $\mathrm{cfu} / \mathrm{g}$ (3.46log cfu/g for the frozen MB and $4.32 \mathrm{cfu} / \mathrm{g}$ for the fresh MB), lower to that reported in United Kingdom in 80s (4.61 $\log \mathrm{cfu} / \mathrm{g} ; 19)$ and more recently to that reported in dromedary minced meat (5.1 $\log \mathrm{cfu} / \mathrm{g} ; 17,2010)$.

If the TC load samples is significantly higher than the value reported in U.S.A. (1.7 $\log \mathrm{cfu} / \mathrm{g} ; 20)$, it nevertheless remains lower than that recorded in Morocco (6 log $\mathrm{cfu} / \mathrm{g}$; 17).

The high rate of TC in the minced beef can be due to inadequate cleaning and disinfection, contaminant materials (ex: packaging), bad conditions of storage, source of untreated water, and deficiency in disinfection treatment.

Fecal coliforms (FC) live in the human and animal intestines; their presence would reflect bad conditions during the slaughter 
operation. They survive difficulty for a long time outside of the intestine so; their presence indicates a recent faecal contamination (8).

The average load FC is $3.08 \log \mathrm{cfu} / \mathrm{g}$ (2.76 $\log \mathrm{cfu} / \mathrm{g}$ for the frozen minced beef and $3.41 \mathrm{log} \mathrm{cfu} / \mathrm{g}$ for the fresh minced beef) lower than those reported in $80 \mathrm{~s}$ (4.31 log cfu/g; 19 and 4 log cfu/g; 14).

Several studies have revealed that fecal coliform (FC) is present in minced beef: in Nigeria; 3-5 log cfu/g (18) and in Morocco, $3.3 \log \mathrm{cfu} / \mathrm{g}(16)$.

This average of high contamination is probably due to the improper handling during slaughtering operation, and to the transformation of the meat into minced meat, or the failure of disinfection materials and non-compliance with the decontamination protocol, or in a defect of material disinfection and failure to respect the decontamination protocol.

The results (4.75 log cfu/g) recorded in Morocco (12) are close to ours while Daabouzi et al. (17) reported a value of 5.5 $\log \mathrm{cfu} / \mathrm{g}$.

No significant differences between the FC of frozen minced beef and FC of fresh minced beef.

Carcass contamination is unavoidable during slaughtering operations, especially during evisceration by the workers hands, equipment, the water used or by the eventual rupture of the gastric reservoir.

A lack of precaution at this level leads probably to direct or crossed contamination. This as well as the contribution of contamination during the transport of carcasses, in butchers, the break of the cold chain or during the mincing process for the minced meat.

\section{Sulfito-reducing}

Clostridium:

Enumeration of sulfito-reducing clostridies is a part of microbiological criterion applicable to food and thus searched by agri-food stuffs and by the competent services (23). Anaerobic sulfito-reducing are telluric commensals of the intestine, exist in two forms, vegetative and very resistant spore used as test of fecal contamination, eventually old.

These germs are considered as "tests germs" for assessing the hygienic quality of animal products. Contamination of ground beef would increase as the product progresses through the grinding process.

The infectious amount for Clostrium perfringens is of $5 \mathrm{log} \mathrm{cfu} / \mathrm{g}$ of food (24). These germs were detected in $67 \%$ of the samples probably related to the crosses between contaminated and healthy sector. $60 \%$ of samples of frozen MB were contaminated with Clostridium against $73.33 \%$ for samples of fresh MB.

The average rates (2.9 log cfu/g) are higher than the Algerian standards (1.47 log $\mathrm{cfu} / \mathrm{g}$ ) since the average charge in sulfitereducing clostridia1.9 log cfu/g for frozen MB and $2.29 \log \mathrm{cfu} / \mathrm{g}$ for fresh MB (Table 1).

These values are much higher than those reported elsewhere in U.S.A.(0.22 log cfu/g, by Emswiler et al., 20), in United Kingdom (0.63 log cfu/g, 19) and in Morocco (1.3 and $1.54 \mathrm{log} \mathrm{cfu} / \mathrm{g}$ in minced beef and 2.7 $\log \mathrm{cfu} / \mathrm{f}$ in dromedary minced meat; 16 ; $12 ; 17)$.

However, some studies suggest that the level of contamination would be greater in the warm season compared to the cold season $(15 ; 16)$.

Strict hygiene measures in slaughterhouses even for all of the food chain are an important criterion to respect in order to minimize the infection risk.

Coagulase-positive staphylococci: Their detection and enumeration allow assessing the risk of food for consumers, given that they are the major species which can eventually produce a proteinic enterotoxin responsible of food poisoning (8).Food causing of staphylococcal intoxications contains an average of $7.84 \mathrm{log} \mathrm{cfu} / \mathrm{g}(25)$.

The occurrence of contamination by this germ reaches $8.3 \%$ of the samples and the level of contamination is of $4.45 \mathrm{log} \mathrm{cfu} / \mathrm{g}$. No significant difference was observed between these meat types (4.28 log cfu/g 
in frozen MB and d $4.61 \log \mathrm{cfu} / \mathrm{g}$ in fresh $\mathrm{MB}$ ).

Several studies have revealed variable prevalence contaminations in minced beef: $69.9 \%$ in Nigeria (18); 21.4 in Turkey (11) an between $16.7 \%$ and $25 \%$ in Morocco $(16 ; 12)$

The charge is lower than the one recorded in Nigeria $(5-7 \log \mathrm{cfu} / \mathrm{g} ; 18)$ but higher to that reported in Turkey (only $5.7 \%$ were above $3 \mathrm{log} \mathrm{cfu} / \mathrm{g}$ (11), in Morocco (2.3 logcfu/g, 16; $2.27 \log \mathrm{cfu} / \mathrm{g}, 12)$ in USA (0.74 log cfu/g; 20) and at UK (0.5 log cfu/g ;19).

According to Dennai et al. (15), the small difference in staphylococci observed between the lowest value $(1.96 \mathrm{log} \mathrm{cfu} / \mathrm{g}$ in winter) and the highest value (2.67 log $\mathrm{cfu} / \mathrm{g}$ in summer) does not allow concluding a significant effect of the season.

In most cases the contamination is due to an improper handling or hygiene conditions when the food is produced in non-industrial setting, mainly because of the lack of equipment required for correct processing (18).

Contamination of minced beef by staphylococci may be due to hygiene defective workers eventually carrier's holders of $S$. aureus. It has been suggested that in raw foods $S$. aureus indicates contamination due to nasopharyngitis or human dermatosis (26).

Salmonella: The presence of Salmonella in frozen MB with a rate of $3.33 \%$ joins other studies that indicate the presence of Salmonella on beef carcasses at rates varying from 0.2 to $21.5 \%$ (27).

Contamination of minced beef with salmonella is regarded the major problem in food hygiene. Indeed, on a basis of modelling exercise at a salmonella outbreak beginning (field data), an infectious dose by person (affecting $50 \%$ of exposed subject) was respectively estimated at $7 \mathrm{cfu}$ (infected person) and 36 cfu (infection and disease-bearing person) (28). Infectious dose by oral route seems higher; $5 \mathrm{log} \mathrm{cfu} / \mathrm{g}$ of food (24). Resistance of salmonella to freezing is known in the literature; in the stored minced meat for 21 days at $-20^{\circ} \mathrm{C}$, survival passes from $0,12 \%$ at pH 4.5 up to $20 \%$ at $\mathrm{pH} 7.5$ (19).

Freezing seems to be a risk factor to Salmonella contamination, which is not conclusive since for some authors, the contamination increases with the outside temperature (29). The presence of Salmonella in minced beef could be explained by contamination from the lymph nodes, viscera, skin and leather of animals, equipment or any manipulators healthy carriers (30). In fact, the man is a natural reservoir of Salmonella typhimurium (31).

Summarized data from several European countries showed that Salmonella prevalence in minced beef ranged from $0.0 \%$ to $3.6 \%$, with a mean of $1.1 \%$ (32). However, in Egypt contamination with salmonella reached $20 \%$ of frozen MB samples (33). Likewise, many researchers such could not detect Salmonella species from samples of minced beef (34). They concluded that this negative result not indicates the absence of the bacteria, but this result may be due to low sensitivity and specificity of the method used in isolation.

A good informing caregiver, implementation of a hygiene plan in slaughterhouses and in cutting and meat preparation companies are crucial.

Yeast and molds: In general, the yeasts are not pathogenic but some as well as molds can be infectious or cause allergic reactions. Content revealed (4.51) is much lower than that reported in Morocco (6.6 $\log \mathrm{cfu} / \mathrm{g} ; 17)$. Nevertheless they exceeded those reported in Turkey $(1.62 \mathrm{log} \mathrm{cfu} / \mathrm{g}$, 35).Their presence in food is often undesirable because they can cause organoleptic alterations.

\section{Conclusion}

Important levels of bacterial contamination were found in the minced beef and globally more important in the fresh meat comparatively to the frozen one. However, the difference is only significant for total 
aerobic mesophilic flora and total coliforms. The meat is regarded as one of the main sources of food-borne diseases; its evaluation can constitute a valuable source of information that can be used in the design of the collective prophylaxis programs in public health. If the majority exceeded the thresholds of regulatory compliance, the analyzed samples showed varying bacterial loads in relation to insufficient hygiene practices. In order to reduce the contamination by pathogenic microbes, it is necessary to set up the measures of best practice at the manufacturing stage in Western Algeria.

\section{References}

1. FAO. (2006). The GEMS/Food Consumption Cluster Diets.http://www.who.int/entity/foodsa fety/chem/ClusterDietsAug06.xls

2. Jouve, J. L. (1990) "Microbiologie alimentaire et filière des viandes," Viandes production carnée. 11(6) bis et ter 207-213.

3. Norme Algérienne NA 647. (1992) Viande et produits à base de viande. Dénombrement des MCO, méthodes par comptage des colonies obtenues à $30^{\circ} \mathrm{C}$ (méthode de référence).

4. International Organization for Standardization (ISO) 17410. (2001) Microbiology of food and animal feeding stuffs. Horizontal method for the enumeration of psychrotrophic microorganisms.

5. International Organization for Standardization (NF ISO) 21527-1. (2008) Microbiologie des aliments. Méthode horizontale pour le dénombrement des levures et moisissures, Partie 1: technique par comptage des colonies dans les produits à activité d'eau supérieure à 0,95.

6. International Organization for Standardization (ISO) 4832. (1991) Méthode horizontale pour le dénombrement des coliformes. Méthode par comptage des colonies. 2 ème éd, 5.
7. International Organization for Standardization $\quad$ (ISO) 6888. (1983) Directive générales pour le dénombrement de Staphylococcus aureus, Méthode par comptage des colonies, 8.

8. Joffin, C. and Joffin J. N. (1999) Microbiologie alimentaire. Edition CRDP.

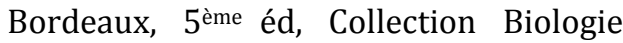
Technique, 211-212.

9. International Organization for Standardization $\quad$ (ISO) 3565. (1975) Viande et produits à base de viande, recherche des Salmonelles, Méthode de référence, 11.

10. Petrie, A. and Watson, P. (2006) Statistics for Veterinary and Animal Science, 2nd ed., Blackwell Science Ltd., Oxford, UK, pp. 299.

11. Siriken, B. (2004) "The microbiological quality of ground beef in Aydin and Afyon Provinces, Turkey," Revue de Médecine Vétérinaire," 155(12) 632-636.

12. Oumokhtar, B., Berrada, H. and Huidson, W. (2008) "Analyse microbiologique de la viande hachée bovine commercialisée à Fès, Maroc," Les Technologies de laboratoire, 12 4-10.

13. Lasta, J., Rodriguez, R. Zanelli, M. and Margaria, C. A. (1992) "Bacterial count from bovine carcasses as an indicator of hygiene at slaughtering places: a proposal for sampling," Journal of Food Protection, 54 271-278.

14. Fathy A. K. A. (1988) Sanitary status of meat products and fish in Beni Suef Governorate. (PhD thesis). Beni Suef university, Egypte, 200 p.

15. Dennaï N., Kharrati B. and El Yachioui, M. (2001) “Appréciation de la qualité microbiologique des carcasses de bovins fraîchement abattus, " Annales de Médecine vétérinaire. 145(4), 270-274.

16. Cohen N., Filliol I., Karraouan, B. et al. (2008) "Microbial quality control of raw ground beef and fresh sausage in 
Casablanca (Morocco)," Journal of Environemental Health, 71(4) 51-55.

17. Daabouzi A, Gamouhi A et al. (2010) "Caractérisation physicochimique et microbiologique de la viande hachée du dromadaire issue des régions de Casablanca, Rabat et salé, " Les technologies de laboratoire, 5(18) 12-16

18. Salihu, M. D., Junaidu A. U., Magaji A. A., Aliyu R. M., Yakubu Y., Shittu A. and Ibrahim M.A. (2010) "Bacteriological quality of traditionally prepared fried ground beef (Dambunnama) in Sokoto, Nigeria," Advance Journal of Food Science Technology, 2(3) 145-147.

19. Roberts T. A., Britton, C. R. and Huidson, W. R. (1980) "The bacteriological quality of minced beef in the U.K.," Journal of Hygiene, 85 211-211.

20. Emswiler, B. S., Pierson, C. J. and Kotula, A. W. (1976) "Bacteriological quality and shelf life of ground beef, " Applied and environmental microbiology, 31(6) 826830.

21. Karaboz, I. and Dincer, B. (2002) "Microbiological investigations on some of the commercial frozen meat in Izmir," Turkish Electronic Journal of biotechnology, Special issue 18-23.

22. Zweifel, C., Fischer, R. and Stephan, R. (2008) "Microbiological contamination of pig and cattle carcasses in different small-scale Swiss abattoirs," Meat Science, 78(3) 225-231.

23. Delarras, C. (2007). Microbiologie pratique pour le laboratoire d'analyse ou de contrôle sanitaire. Edition Technique et documentation. Paris, 88-248.

24. Benhote, P. (2011). Elévation du niveau d'hygiène dans la restauration. Master in advanced studies food safety services. Université de bâle. P 71.

25. Gilbert, R. J. Wieneke, A. A. et al. (1972) "Serological detection of enterotoxin in foods implicated in staphylococcal food poisoning, " Journal of Hygiene, 70 755762 .

26. International Biological Standards Commission relating to food, (1974) Sampling for microbiological analysis: principles and specific applications. University of Torento press.

27. D'Aoust, Y.V. (1989). Salmonella. In: Food born bacterial pathogens. Ed: Doyle M P. Marcel Dekker, Inc New York, 327413.

28. Teunis, P.F., Kasug, A.F., Fazil, A., Ogden, I. D., Rotariu O. and Strachan N. J. (2010) "Dose-response modeling of Salmonella using outbreak data," International Journal of Food Microbiology. 144(2) 243249.

29. Klein, G. and Louwers, J. (1994) "Microbiological quality of fresh and stored ground meat from commercial production," Berl. Münch. Tierarztl. Wochenschr,107 361-367.

30. Reid, C. A., Small, A. Avery, S. M. and Buncic, S. (2002) "Presence of foodborne pathogens on cattle hides," Food Control, 13(6-7) 411-451.

31. Karib H., Bazri L., Yanguela, J., Blanco, D., Herrera, A. (1994) “Appréciation de l'hygiène des abattoirs par l'analyse bactériologique des carcasses bovines," Viandes et production carnée, 15 79-82.

32. Anon (2006) "The community summary report on trends and sources of zoonoses, zoonotic agents, antimicrobial resistance and foodborne outbreaks in the European Union in 2005," The European Food Safety Authority Journal, 94 3-288.

33. Hassanein, R., Hassan Ali, S. F., Abd ElMalek, A. M., Mohamed M. A. and Elsayh, K. I. (2011) "Detection and identification of Salmonella species in minced beef and chicken meats by using Multiplex PCR in Assiut city," Veterinary World, 4(1) 5-11.

34. Fathi, S. H. M. and Thabet, A. El-R. (2001) "Incidence of Salmonella and E.

Bouzid R., Guemour D., Zidane K.,Aggad H., Bendella A., Saegerman C. (2015), Journal of Virology \& Microbiology, DOI: 10.5171/2015.124808 
coli in packed meat products sold in Assiut city," Assiut Veterinay Medicine Journal, 46(91) 187-199.

35. Gungor, E. and Gokoglu, N. (2010) "Determination of microbial contamination sources at a Frankfurter sausage processing line," Turkish Journal of Veterinary and Animal Science, 34(1) 53-59 